\title{
Characterization of a new apple luteovirus identified by high-throughput sequencing
}

Huawei Liu', Liping Wu ${ }^{1,2}$, Ekaterina Nikolaeva ${ }^{3}$, Kari Peter ${ }^{4}$, Zongrang Liư ${ }^{5}$, Dimitre Mollov', Mengji Cao ${ }^{6}$ and Ruhui $\mathrm{Li}^{1^{*}}$

\begin{abstract}
Background: 'Rapid Apple Decline' (RAD) is a newly emerging problem of young, dwarf apple trees in the Northeastern USA. The affected trees show trunk necrosis, cracking and canker before collapse in summer. In this study, we discovered and characterized a new luteovirus from apple trees in RAD-affected orchards using high-throughput sequencing (HTS) technology and subsequent Sanger sequencing.

Methods: Illumina NextSeq sequencing was applied to total RNAs prepared from three diseased apple trees. Sequence reads were de novo assembled, and contigs were annotated by BLASTX. RT-PCR and 5'/3' RACE sequencing were used to obtain the complete genome of a new virus. RT-PCR was used to detect the virus.

Results: Three common apple viruses and a new luteovirus were identified from the diseased trees by HTS and RT-PCR. Sequence analyses of the complete genome of the new virus show that it is a new species of the genus Luteovirus in the family Luteoviridae. The virus is graft transmissible and detected by RT-PCR in apple trees in a couple of orchards.

Conclusions: A new luteovirus and/or three known viruses were found to be associated with RAD. Molecular characterization of the new luteovirus provides important information for further investigation of its distribution and etiological role.
\end{abstract}

Keywords: Rapid apple decline, USA, Luterovirus, Genomic sequence

\section{Background}

Apple (Malus domestica L.) is the most widely cultivated fruit crop worldwide [1]. The U.S. is the world's secondlargest producer of apple with a wholesale value of $\$ 4$ billion (https://www.usapple.org/all-about-apples/appleindustry-statistics/). Apple is propagated by grafting, budding and layering. The careless selection of infected materials for the propagation allows the accumulation of virus/viruses in apple trees and dissemination of viruses between trees, orchards and regions. At least ten viruses and four viroids have been reported to infect apple trees, causing many types of diseases that reduce fruit quality and yield [2]. Among the most commonly reported viruses are apple stem pitting virus (ASPV), apple stem grooving virus (ASGV) and apple chlorotic leaf spot

\footnotetext{
* Correspondence: Ruhui.li@ars.usda.gov

${ }^{1}$ USDA-ARS, National Germplasm Resources Laboratory, Bldg. 004/Rm 015, Beltsville, Maryland 20705, USA

Full list of author information is available at the end of the article
}

virus (ACLSV), all species of the family Betaflexiviridae. These viruses are ubiquitous and frequently occur as mixed infections. They are commonly called latent viruses because they usually do not induce obvious symptoms in most cultivars used in production, although yield reductions have been reported [3].

For the last several years, an unusual problem of young, apple trees growing of dwarfing rootstock in the northeastern U.S. has been observed (https://extension.psu.edu/ apple-disease-rapid-apple-decline-rad-or-sudden-apple-decline-sad). The problem has been named 'Rapid Apple Decline' (RAD) or 'Sudden Apple Decline' due to the rapid or sudden death of apple trees after the first appearance of symptoms (Fig. 1). Several scion cultivars start to decline after grafting onto the M9 rootstock. The affected trees usually exhibit cankers and cracks on the rootstock and/or scion trunks. Necrosis begins at the graft union and proceeds up the trunks. The leaves of some affected trees begin 


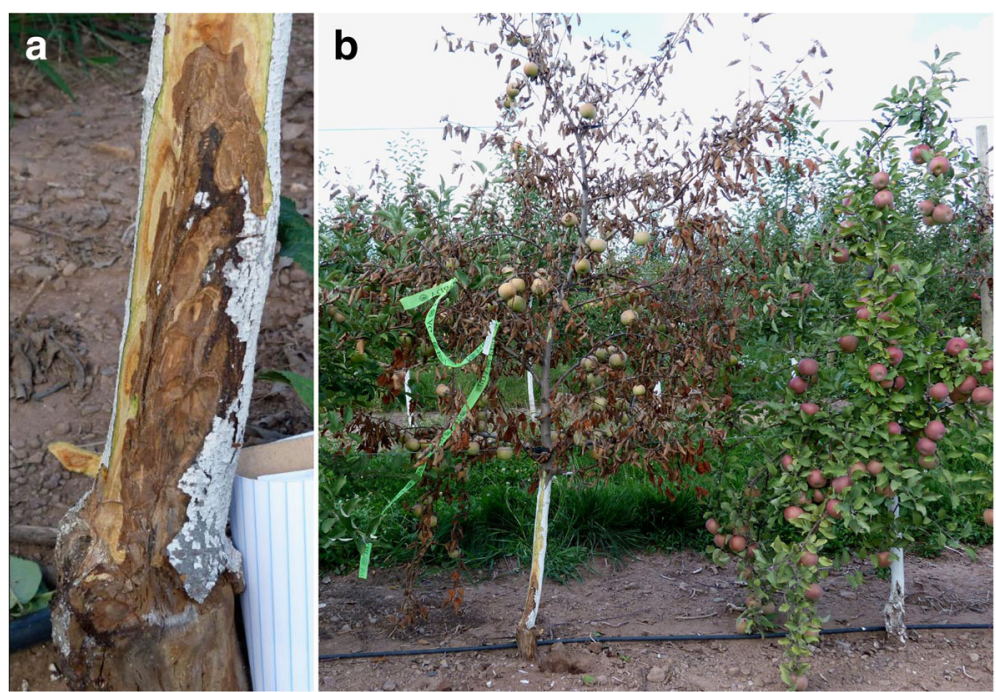

Fig. 1 Symptoms of rapid apple decline. Necrosis of the graft union (a) and rapid collapse (b) of an apple cv. Fuji tree grafted on M9 rootstock

to look yellow and then redden, and within two weeks the trees collapse from late July through September.

The involvment of fire blight and other pathogens [phytophthora and tomato ringspot virus (ToRSV)], herbicide damage, winter and drought injuries in RAD has been largely ruled out through rigorous observations and/or testing. This prompted us to use highthroughput sequencing (HTS) to further investigate possible causal agent(s) of RAD.

HTS combined with bioinformatic analyses is becoming a routine technology in the field of plant virology for the discovery of many new and emerging viruses, detection of known viruses and investigation of viral genetic diversity and evolution [4]. In this study, Illumina RNA sequencing technology was used to identify the pathogens potentially associated with RAD, including a new luteovirus tentatively named apple luteovirus 1 .

\section{Methods}

\section{Sample collections and preparations}

In June 2016, samples of branches were collected from six RAD symptomatic apple trees (Table 1; PA2, PA4, PA5, PA7, PA8 and PA9) in a 5-year-old orchard at the Pennsylvania State University Fruit Research and Extension Center (PSU-FREC). The apple cultivar was Crimson Crip grafted on M9 rootstock. Two samples, one from scion and another from rootstock suckers, were collected from each tree. For HTS analysis, total nucleic acids were extracted from leaf, petiole and bark tissues by a CTAB method [5] and used for total RNA isolation by RNeasy Plant Mini Kit (Qiagen, Germantown, MD). TNA by the CTAB method were used for the detection of all four viruses.
High-throughput sequencing and analyses

Total RNAs of three pooled samples, CPAR (all 6 rootstock samples), CPAS1 (scion samples of PA2, PA4 and PA5) and CPAS2 (scion samples of PA7-9), were processed at SeqMatic (Fremont, CA). Plant ribosomal RNAs (rRNA) were removed from total RNAs using Illumina Ribo-Zero rRNA Removal Kit for cDNA library construction. The samples were sequenced on the Illumina NextSeq sequencing platform with 15-sample bar-coded multiplexing.

Analyses of total sequence reads were performed using the CLC Genomics Workbench 9.5.2 platform (https:// www.qiagenbioinformatics.com/). The raw reads were filtered to remove the failed reads, and qualified reads were assembled de novo into contigs with a cut-off of 150-nt. Contigs were annotated by BLASTx comparisons to Viruses_NR and Viroids databases downloaded from NCBI GenBank databases.

\section{Validation of the viruses and genome determination of a new luteovirus}

To verify the presence of a new luteovirus in the six samples used in HTS, RT-PCR using primers AluDetF6/ R6 (Additional file 1) were used. The three latent viruses were also detected by RT-PCR using virus-specific primers (Additional file 1) designed based on alignments of their genomic sequences available in GenBank. The RT-PCR was performed using the SuperScript ${ }^{\text {tw }}$ III OneStep RT-PCR System (Invitrogen, Carlsbad, CA, USA) in a 20- $\mu \mathrm{l}$ reaction containing $1 \mu \mathrm{l}$ of TNAs, $1.0 \mu \mathrm{l}$ of each primer $(5 \mu \mathrm{M}), 10 \mu \mathrm{l}$ of $2 \times$ Reaction Mix, $0.4 \mu \mathrm{l}$ of Enzyme Mix and $6.6 \mu \mathrm{l}$ of water. The thermal cycling conditions for RT-PCR were 1 cycle of $50{ }^{\circ} \mathrm{C}$ for $30 \mathrm{~min}$ and $94{ }^{\circ} \mathrm{C}$ for $2 \mathrm{~min}, 35$ cycles of $94{ }^{\circ} \mathrm{C}$ for $30 \mathrm{~s}, 55-60{ }^{\circ} \mathrm{C}$ 
Table 1 Cultivars, symptoms and viruses of apple trees in a research block

\begin{tabular}{|c|c|c|c|c|c|c|}
\hline \multirow[t]{2}{*}{ Sample ${ }^{a}$} & \multirow[t]{2}{*}{ Cultivar $^{\mathrm{b}}$} & \multirow[t]{2}{*}{ Symptoms ${ }^{c}$} & \multicolumn{4}{|l|}{ Virus $^{d}$} \\
\hline & & & ALV 1 & ACLSV & ASGV & ASPV \\
\hline PA2 & Crimson Crisp & Trunk cracking, leaf yellowing & + & + & + & + \\
\hline PA4 & Crimson Crisp & Trunk cracking, leaf yellowing & + & - & + & + \\
\hline PA5 & Crimson Crisp & Trunk cracking, leaf yellowing & + & + & + & + \\
\hline PA7 & Crimson Crisp & Trunk cracking, leaf yellowing & + & - & + & - \\
\hline PA8 & Crimson Crisp & Trunk cracking, leaf yellowing & + & - & - & + \\
\hline PA9 & Crimson Crisp & Trunk cracking, leaf yellowing & + & - & - & - \\
\hline PA11 & Crimson Crisp & NS & + & + & + & + \\
\hline PA12 & Crimson Crisp & NS & + & + & + & + \\
\hline PA13 & Crimson Crisp & Bark cracking & + & + & + & + \\
\hline PA14 & Crimson Crisp & NS & + & + & + & + \\
\hline PA15 & Crimson Crisp & Upper branch browning & + & + & - & + \\
\hline PA16 & Crimson Crisp & NS & + & + & + & + \\
\hline PA17 & Crimson Crisp & Leaf distortion, tree dying & + & + & + & + \\
\hline PA18 & Fuji & Trunk cracking, leaf curl & + & - & + & - \\
\hline PA19 & Fuji & NS & - & - & - & - \\
\hline PA20 & Gala & Trunk cracking, small leaves & + & + & + & - \\
\hline PA21 & Fuji & NS & + & - & - & - \\
\hline PA22 & Gala & NS & + & + & - & + \\
\hline PA23 & Golden Delicious & Trunk cracking, leaf curl & + & - & + & - \\
\hline PA24 & Golden Delicious & NS & + & - & - & - \\
\hline
\end{tabular}

${ }^{\mathrm{a}}$ Samples PA2-9 were collected in June 2016

${ }^{\mathrm{b}}$ All cultivars were grafted on $\mathrm{M} 9$ rootstock

${ }^{\mathrm{C}} \mathrm{NS}$ mean that there were no obvious symptoms

${ }^{c} A L V 1$ Apple luteovirus 1, ACLSV Apple chlorotic leaf spot virus, ASGV Apple stem grooving virus, ASPV Apple stem pitting virus

(varied according to the primer pairs) for $1 \mathrm{~min}$ and $68^{\circ} \mathrm{C}$ for $40 \mathrm{~s}$ and one final extension at $68{ }^{\circ} \mathrm{C}$ for $5 \mathrm{~min}$.

To obtain the complete genomic sequence of the new luteovirus, primers were designed based on the contig sequences with similarity to several luteroviruses (Additional file 1). The TNAs of the PA8 sample (Table 1) was used as template in the RT-PCR. The $5^{\prime}$-end sequence was obtained by a 5'RACE System Kit (Invitrogen). The 3'-end sequence was determined by a First Choice RLM-RACE Kit (Invitrogen) after polyadenylation of the RNAs using poly(A) polymerase (New England BioLabs, Ipswich, MA). All amplicons were cloned into pGEM-T Easy Vector (Promega, Madison, WV), and plasmid DNAs isolated from overnight cultures were sequenced (MCLAB, San Francisco, CA).

\section{Genomic sequence analysis of the luteovirus}

The sequences were assembled and analyzed by the CLC Genomics Workbench. Open reading frames (ORFs) were predicted using the Open Reading Frame Finder at https://www.ncbi.nlm.nih.gov/orffinder/. Multiple alignments of genomic sequences and deduced amino acid sequences of individual viral genes were performed by the neighbor-joining algorithm as implemented in ClustalW, and the resulting alignments were analyzed using MEGA7 [6]. Recombination analysis was carried out using RDP 4.83 package [7].

\section{Graft transmission of the luteovirus}

To verify the luteovirus sequences are associated with graft-transmissible agents, dormant buds of each of four selected trees from the PSU block (Table 1; PA13, PA14, PA18 and PA21) were grafted onto seven apple seedling trees. All seedlings tested negative for the luteovirus and three latent viruses. PA21 is infected with the luteovirus alone, but PA13, PA14 and PA18 are mix infected with at least one latent virus. Leaves were collected from new shoots of each of the inoculated seedlings at one, five and seven months after grafting. TNA were extracted from leaf and petiole tissue and used as template in by RT-PCR as described above. An uninoculated apple seedling was used as negative control.

\section{Additional detection of the luteovirus}

Eighty samples were collected from both RAD symptomatic and symptomless apple trees from PSU-FREC 
and USDA-ARS Appalachian Fruit Research Station (AFRS) in West Virginia (Table 2). The FREC trees in Pennsylvania were grafted on M9 rootstock, whereas the AFRS trees were grafted on EMLA 7 rootstock. A symptomatic tree (PA14) infected with the luteovirus and three latent viruses and an apple seedling were used as controls. TNAs prepared from leaves, petioles and bark were used as templates in RT-PCR, as described above. Viral amplicons of selective samples of each location were cloned and sequenced by Sanger sequencing.

\section{Results}

Virus identification by high-throughput sequencing

Total reads of 27,727,559 (CPAR), 28,817,295 (CPAS1) and 30,614,167 (CPAS2) were obtained after removing the failed reads. Assembly de novo of the reads generated a total of 59,415 (CPAR), 60,992 (CPAS1) and 65,115 (CPAS2) contigs larger than 150 nt. Blastx searches against the Viruses_NR database revealed contigs with amino acid (aa) sequence identities of 29-76\% to peach associated luteovirus (PaLV), cherry associated luteovirus (ChaLV) and rose spring dwarf associated virus (RSDaV) of the genus Luteovirus in the family Luteoviridae from CPAR (2 contigs), CPAS1 (6 contigs) and CPAS2 (2 contigs), respectively. Approximately $335,446(86 \times)$, 48,908 (12×) and 778,086 (199x) reads were mapped to contig CPAS1-8, the longest luteovirus contig, supporting the presence of the virus in the three samples. Multiple contigs with identities of $83-99 \%$ to ACLSV, ASGV and ASPV were also identified from all three samples, respectively, but the data are not presented here. No viroid was detected from any of the HTS samples.

\section{RT-PCR detection the viruses in orchard samples}

The luteovirus was detected in all six HTS samples $(6 / 6$, $100 \%)$, whereas ACLSV (2/6, 33\%), ASGV (4/6, 67\%) and ASPV (4/6, 67\%) were only found in some of these trees (Additional file 2). PA9 was infected with the luteovirus alone, whereas five other trees were infected with at least one latent virus. Fourteen more samples consisting of four different cultivars were collected from the same PSU-FREC orchard and tested by RT-PCR. The luteovirus was detected in 13 of them (93\%) (Table 1). The latent viruses were again detected from fewer samples (ACLSV 64\%, ASGV 64\% and ASPV 57\%).

To expand the testing for the luteovirus, a total of 80 additional samples were collected from the PSU-FREC and AFRS orchards (Table 2). Some trees in the PSUFREC orchard showed the disease symptoms, whereas those in the AFRS orchard did not have obvious symptoms. Results of RT-PCR showed that majority of $\mathrm{cv}$. Fuji trees (11/12) and a small number of cv. Gala (2/12) and Gold Delicious (2/12) trees in the PSU-FREC orchard were infected with ALV-1, but the infection rates were much lower for the cultivars in the AFRS orchard.

\section{Graft transmission}

The graft inoculated apple seedlings did not display obvious symptoms nine months after inoculation. Infections of the luteovirus and latent viruses were confirmed by RT-PCR using specific primers, respectively (Additional file 1). A weak amplification was obtained from the PA21 seedlings one month after inoculation (data not shown), and all four samples tested positive five months after inoculation (Additional file 3).

\section{Complete genome of the luteovirus}

Complete genome of the new virus, with the proposed name apple luteovirus 1 (ALV-1), is 6001 nucleotides (nt) in size (GenBank no. MF120198), encoding ten open reading frames (ORFs). The genome starts with a conserved element ${ }^{1}$ GTGAUU ${ }^{6}$ (underlined nt is different from other species of Luteovirus) and contains all cisacting elements of the luteoviruses [8,9]. The conserved ${ }^{1364}$ GGAUUUUUAGAGGGGCU ${ }^{1380}$ and ${ }^{1392}$ CCGGC UUUGÄAUCCCC $\overline{U U U}^{1410}$ known to be responsible for the -1 ribosomal frameshift are located at the junction of ORF1 and ORF2. A tract of ten tandem CCXXXX (X is any base) repeats that is required for the ORF3 stop

Table 2 Apple samples used for detection of apple luteovirus ${ }^{a}$

\begin{tabular}{|c|c|c|c|c|}
\hline Location $^{a}$ & Collection date & Cultivar $^{\mathrm{b}}$ & Number of samples & Infection rate \\
\hline PSU-FREC & $09 / 16 / 2014$ & Fuji & 12 & $11(91.6 \%)$ \\
\hline \multirow[t]{2}{*}{ Pennsylvania } & & Gala & 12 & $2(16.7 \%)$ \\
\hline & & Gold Delicious & 12 & $2(16.7 \%)$ \\
\hline AFRS & $01 / 31 / 2017$ & Crimson Crisp & 13 & $4(30.7 \%)$ \\
\hline \multirow[t]{3}{*}{ West Virginia } & & Fuji & 11 & $1(9.1 \%)$ \\
\hline & & Hampshire & 10 & 0 \\
\hline & & Snapp Stayman & 10 & $1(10.0 \%)$ \\
\hline Total & & & 80 & $21(26.3 \%)$ \\
\hline
\end{tabular}

a PSU-FREC Pennsylvania State University-Fruit Research and Extension Center, AFRS Appalachian Fruit Research Station

${ }^{b}$ Cultivars in the PSU-FREC orchard were grafted on M9 rootstock, and cultivars in the AFRS orchard were grafted on EMLA 7 rootstock 
codon readthrough starts at nt 3695 . The $3^{\prime}$ terminal region contains all conserved elements [8] but the longest motif at the first stem-and-loop of the barley yellow dwarf virus-like element (BTE) is different as ${ }^{5503}$ GUACGUCCUGGUAGAACAGG ${ }^{522}$ (bolded and italicized nt represents inserted nt). These two insertions, ${ }^{5506} \mathrm{CG}^{5507}$ and ${ }^{5516} \mathrm{G}$, are unique to ALV-1.

The arrangement and structure of six of these ORFs (ORF1, ORF2, ORF3, ORF3a, ORF4 and ORF5) resembles that of other luteoviruses (Fig. 2a) [8, 10-14]. The ORF1 and ORF2 encode putative P1 and P1-P2 fusion proteins (by the -1 frameshift translation), respectively, and together they form a putative replicase complex. The ORF3 encodes a putative coat protein $(\mathrm{CP})$, and translation via read-through of its stop codon produces a putative P3-P5 fusion protein that might be involved in insect transmission. The ORF4 encodes a putative movement protein (MP). Like most luteoviruses, ALV-1 also encodes a small ORF3a (nt 2956-3093) that is essential for long distance movement [15]. ORF6 and ORF7 are only present in some luteoviruses [11, 13, 14], and ORF1a and ORF5a are unique to this virus. ORF1a embedded within ORF1 is in a similar position to ORF0 of species of the genus Enamovirus [16] but its gene product (264 aa residues) does not share any sequence similarity to the enomovirus ORF0. ORF5a within ORF5 encodes a putative protein of 96 aa residues. The putative proteins encoded by ORF1a and ORF5a have no sequence homology with any known proteins.

\section{Sequence comparisons and phylogentic analysis of the luteovirus}

Comparisons of genomic and individual protein sequences among species in the family Luteoviridae confirmed that ALV-1 is most closely related to PaLV (Fig. $2 b)$. The genome sequence identities between the two viruses is $53 \%$ at the nucleotide sequence level, which falls within range of $48-69 \%$ among the luteoviruses [17]. Sequence comparisons showed that the P1-P2 replicase was the most conserved (52-63\%), whereas the P4 (MP) was the least conserved (27-39\%) between ALV-1 and known luteoviruses at aa sequence level. Except for the P3a, ALV-1 had the highest aa sequence identity with PaLV or ChALV at the individual proteins. The P3a of ALV-1 was most closely related to soybean mosaic virus (SMV). According to the species demarcation criteria for the family Luteoviridae ( $\geq 10 \%$ difference in aa sequence

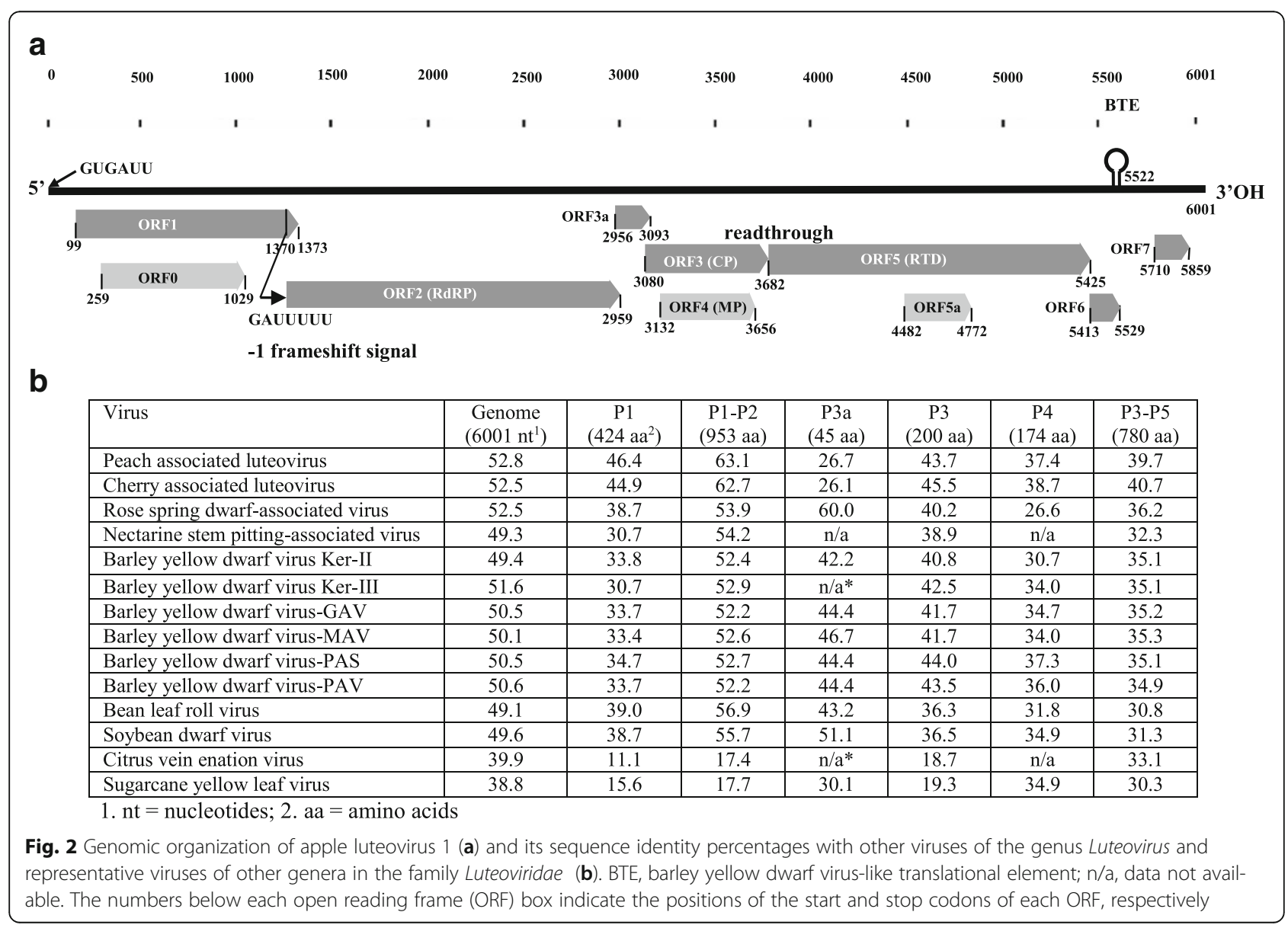


of any gene) [17], ALV-1 should be a new species of the genus Luteovirus.

Phylogenetic analyses conducted using the genomic sequences of ALV-1 and other luteoviruses placed the virus with ChALV, PaLV, RSDaV and nectarine stem pitting-associated virus (NSPaV) in a cluster distinct from that of BDYVs and two legume luteoviruses (Fig. $3)$. Topologies of phylogenetic trees changed slightly when the aa sequences of the P1-P2 and CP aa sequences were analyzed but close relationship of the four viruses were retained (data not shown). Analysis of the genomic sequences of 45 species of the family Luteoviridae by RDP4 did not detect any recombination breakpoints.

\section{Discussion}

A novel luteovirus provisionally named apple luteovirus 1 and three common viruses (ACLSV, ASGV and ASPV) were identified by HTS of total RNA extracted from RAD-affected apple trees. BLAST search in pathogen databases identified several contigs showing similarities with members of the genus Luteovirus in the family Luteoviridae, particularly with four known luteoviruses
(ChALV, NSPaV, PaLV and RSDaV) that infect woody plants [11-14]. The 6001-nt genomic sequence of ALV1 is the largest genome of the known luteoviruses due to insertions in ORF1, ORF3 and ORF5. The arrangement and structure of the ALV-1 genome resembles those of other luteoviruses, containing six hallmark ORFs of the genus (Fig. 2a), encoding proteins involved in replication (P1 and P1-P2 fusion protein), virion assembly (CP), movement (P3a and P4) and aphid transmission (P3-P5 fusion protein) [9-11]. The ALV-1 genome also has several unique features. The 17-nt BTE motif conserved in the 3' terminus of all known luteoviruses changes to ${ }^{5503}$ GUACGUCCUGGUAGAACAGG ${ }^{522}$ in ALV-1 due to two insertions (bolded and italicized bases), making it a unique motif among the luteoviruses. The ALV-1 genome also contains two additional ORFs ( $1 \mathrm{a}$ and $5 \mathrm{a}$ ) that are not present in any known luteoviruses. Pairwise comparisons showed that ALV-1 has the highest genomic sequence identity (52.8\%) with PaLV [14], indicating ALV-1 is a distinct species of the genus Luteovirus. Phylogenetic analysis also placed ALV-1 with the woody plant-infecting luteoviruses, suggesting that these viruses share a common ancestor.

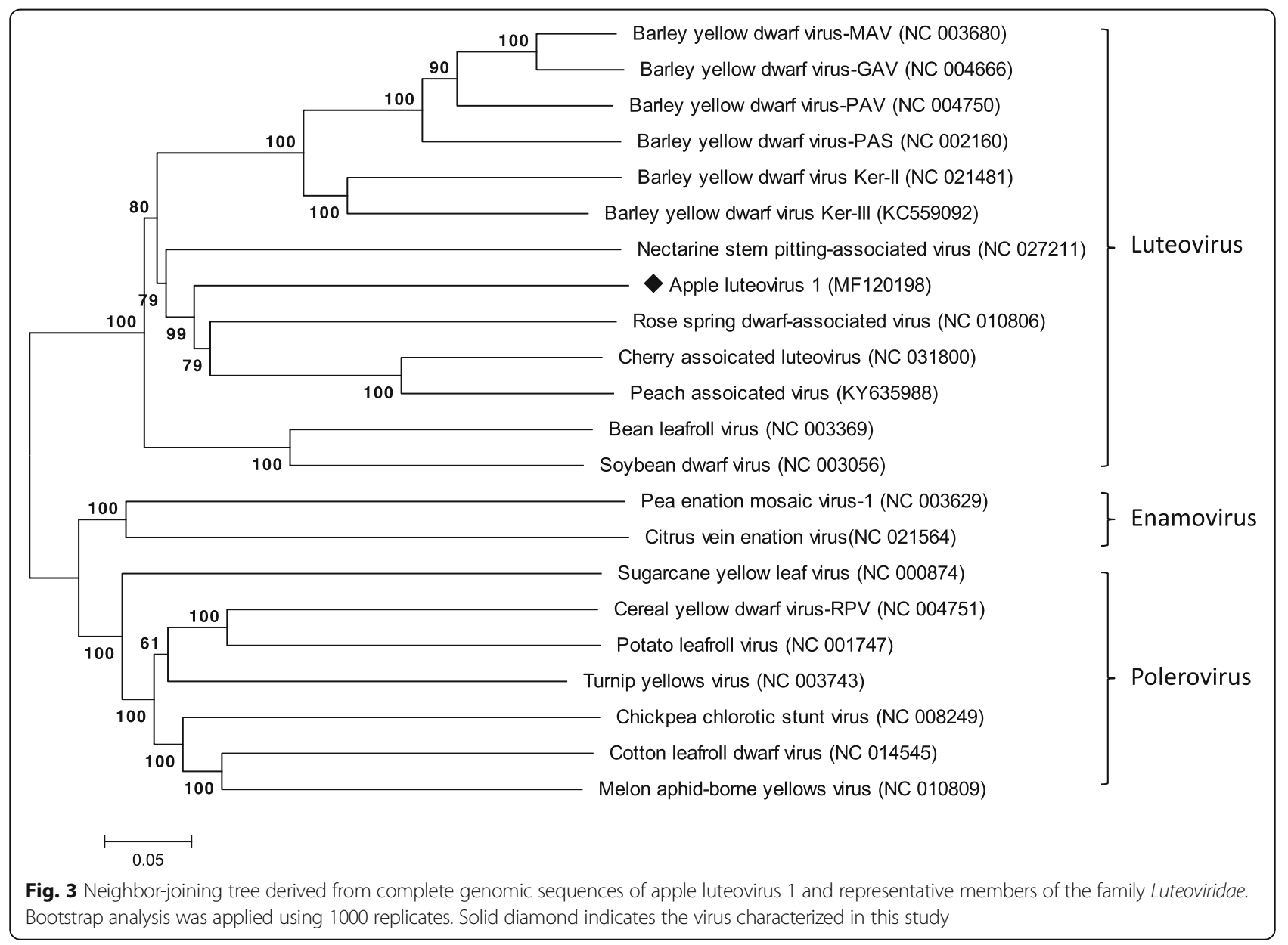


Recombination plays an important role in evolution of plant RNA viruses. Both bean leafroll virus and SMV are recombinants occurred before the species separation [17]. It is a pervasive phenomenon among BYDV species and isolates [18]. However, recombination analysis did not reveal any recombination events in the ALV evolution.

Graft inoculation of apple seedlings demonstrated that ALV-1 is graft transmissible, and the virus could be spread by vegetative propagation of scions or rootstock or both. The source of this luteovirus is unknown, and subsequent study of rootstock and mother trees of different apple cultivars is necessary to determine the original infection.

Symptoms of RAD are very similar to apple union necrosis and decline (AUND) described in New York in early 1980s [19]. The eight apple cultivars propagated on MM106 rootstock showed graft union necrosis and tree decline. Similar diseases such as citrus tristeza quick decline disease (T-QD) [20] and citrus sudden death (CSD) have described in citrus trees [21]. T-QD destroyed millions of sweet citrus trees (Citrus sinensis L. OSb.) propagated on sour citrus rootstock ( $C$. aurantium L.) worldwide many years ago [19], and CSD has started to kill hundreds of thousands of sweet oranges propagated on Pangpur lime rootstock (C. limonia L. OSb.) in Brazil since 1999 [20]. T-QD is caused by citrus tristeza virus (CTV), and CSD has been associated with citrus sudden-death associated virus $(\mathrm{CSDaV})$, a species of the genus Marafivirus in the family Tymoviridae. RAD is only observed on apple trees grafted on certain dwarf rootstock cultivars such as M9. Both T-QD and CSD also occurred only on sweet orange grafted on certain rootstock [20, 21]. T-QD was controlled by replacement of the sour orange rootstock with CTV-tolerant rootstock such as Rangpur lime and Volkamer lemon.When examined by RT-PCR assay, ALV-1 was detected by RTPCR in trees from the RAD-affected orchard (Tables 1 and 2). However, not all ALV-1-infected trees showed trunk cracking and foliar yellowing (Table 1). Similar results were obtained from AUND-, T-QD- and CSDaffected orchards. In AUND-affected orchards, the majority (93\%) of the symptomatic trees and a few asymptomatic trees tested positive for ToRSV, a virus not detected in the RAD-affected orchard [19]. CTV was detected from both symptomatic and asymptomatic trees [20]. Trunk sectioning of a few trees in the PSUFREC orchard revealed that an asymptomatic tree also had necrosis near the graft union, and length of the necrosis was correlated with severity of RAD (data not shown). This study suggested the symptoms on the trunk develop gradually in affected trees. Citrus trees infected with $\mathrm{CSDaV}$ have an incubation period of at least two years before symptoms of sudden death are observed [21]. Similarly, apple trees may remain functional and healthy in early infection before appearance of the tree decline and trunk symptoms such cracks and cankers, which could be caused by secondary fungal/bacterial infection on the trees weaken by the virus infection. The ALV-1 titer may also vary in different parts of an infected tree and from season to season due to the phloem limitation of the luteovirus, affecting the RT-PCR detection of ALV-1. Further study is needed to correlate the symptom development and ALV-1 infection on asymptomatic apple trees in orchards and apple seedlings inoculated with singly infected sources such as PA21.

ALV-1 was detected in both PSU-FREC and AFRS orchards, but RAD was only observed in the PSU-FREC orchard. Although most cultivars in the two orchards are different and have different infection rates, ALV-1 is detected in the common cv. Fuji trees. However, RAD was not observed in the Fuji tree block in the AFRS orchard where EMLA 7 rootstock was used. Therefore, M9 may be susceptible to ALV-1. Occurrence of AUND, T-QD and CSD had been associated with trees grafted on virus-susceptible rootstocks, respectively [19-21]. Replacement of the sour orange rootstock with CTVtolerant rootstocks controlled T-QD [20]. Further investigation of ALV-1 infection in different rootstocks and scion-rootstock combinations is necessary to understand the role of susceptible rootstocks in RAD.

Nothing is known about the vector transmission of ALV-1. Salem et al. [22] reported that RSDaV is transmitted by rose-grass aphid (Metapolophium dirhodum Walker) and yellow rose aphid (Rhodobium porosum Sanderson). The aphid transmission of ChALV, NSPaV and PaLV has not been studied yet. Although aphids were observed in some RAD-affected orchards, their role in spreading ALV-1 in orchards needs to be defined.

Koch's postulates have not yet been fulfilled so we cannot yet conclude that ALV-1 is a causal agent of RAD. The ALV-1 infection in the PSU-FREC orchard affected with RAD is very common, with $93 \%$ of the trees tested positive for ALV-1 and 57-64\% tested positive for the three apple latent viruses (Table 1). Mix infection of the viruses in the RAD-affected orchard makes it difficult to associate ALV-1 with RAD. We are conducting bud grafting inoculation of ALV-1 on few apple cultivars grafted on M9 and other rootstocks to determine the role of ALV-1 in RAD.

The identification of a novel luteovirus in apple broadens the host range of the luteoviruses. Detecting ALV-1 from the RAD-affected trees justifies investigations of the role of this virus in the etiology of this newly emerging problem. The genomic sequence of ALV-1 obtained in this study enables the development of a specific RT-PCR for the rapid detection of the virus. This is 
important to study the distribution, transmission and pathogenicity of ALV-1.

\section{Conclusion}

This paper reports the identification of a new luteovirus and/or three known viruses associated with RAD in Northeast USA. The genome of apple luteovirus 1 was obtained, and the virus was proven to be transmitted by grafting. These data provide important information for further investigation of the role of ALV-1 in RAD.

\section{Additional files}

\section{Additional file 1: Primers used in this study. (DOCX $13 \mathrm{~kb}$ )}

Additional file 2: Virus detection by RT-PCR in RAD-affected apple trees used for high-throughput sequencing. The four viruses are apple luteovirus 1 (ALV-1), apple chlorotic leaf spot virus (ACLSV), apple stem grooving virus (ASGV) and apple stem pitting virus (ASPV), respectively. Lanes M) $1 \mathrm{~kb}$ plus DNA ladder, and W) water. Arrow indicate the DNA fragment with labeled size. (PPTX $226 \mathrm{~kb}$ )

Additional file 3: Verification of graft transmission of apple luteovirus 1 to apple seedlings by RT-PCR using primers AluDetF6/R6 (Additional file 1). Lanes M) 1 kb plus DNA ladder; 1-3) from PA13; 4-6) from PA14; 7-9) from PA18; 10-12) from PA21; 13) PA14; 14) water. Arrow indicate the DNA fragment with labeled size. (PPTX $157 \mathrm{~kb}$ )

\section{Abbreviations}

ACLSV: Apple chlorotic leaf spot virus; ALV-1: Apple luteovirus 1; ASGV: Apple stem grooving virus; ASPV: Apple stem pitting virus; ChaLV: Cherry associated luteoviruses; HTS: High-throughput sequencing; NSPaV: Nectarine stem pitting-assoicated virus; nt: Nucleotide; ORF: Open reading frame; PaLV: Peach associated luteovirus; RAD: Rapid apple decline; RSDaV: Rose spring dwarf-associated virus

\section{Acknowledgements}

The authors would like to thank Sam Grinstead, Tammy Jones and Brian Lehman for excellent technical assistance and Dr. Gary Kinard for critical review of the manuscript.

\section{Funding}

This work was funded by U.S. Department of Agriculture, Agriculture Research Service under research project 1215-22000-302-00D "Characterizing and Detecting Pathogens to Ensure Safe Exchange of Plant Germplasm".

\section{Availability of data and materials}

The datasets used and/or analyzed during the current study are available from the corresponding author on reasonable request.

\section{Authors' contributions}

Conceived and designed the experiments: RL, HWL, LPW. Performed the experiments: HWL, LPW, RL, EN, KP. Analyzed the data: RL, HWL, LPW. Contributed reagents/materials/analysis tools: ZL, DM, MJC. Wrote the paper: RL, HWL. Supervised the study: RL. Edited the final manuscript: EN, KP, ZL. All authors read and approved the final manuscript.

Ethics approval and consent to participate Not applicable.

\section{Competing interests}

The authors declare that they have no competing interests.

\section{Publisher's Note}

Springer Nature remains neutral with regard to jurisdictional claims in published maps and institutional affiliations.

\section{Author details}

'USDA-ARS, National Germplasm Resources Laboratory, Bldg. 004/Rm 015, Beltsville, Maryland 20705, USA. ${ }^{2}$ School of Life Science, Nanchang University, Nanchang 330031, Jiangxi, China. ${ }^{3}$ Pennsylvania Department of Agriculture, Harrisburg, Pennsylvania 17110, USA. ${ }^{4}$ Pennsylvania State University, Biglerville, Pennsylvania 17307, USA. ${ }^{5}$ USDA-ARS, Appalachian Fruit Research Station, Kearneysville, West Virginia 25430, USA. ${ }^{6}$ Citrus Research Institute, Southwest University, Chongqing 400712, China.

Received: 9 January 2018 Accepted: 6 May 2018

Published online: 15 May 2018

\section{References}

1. Juniper BE, Watkins R, Harris SA. The origin of the apple. Acta Hort. 1998; 484:27-34.

2. Barba M, llardi V, Pasquini G. Control of pome and stone fruit virus diseases. Adv Virus Res. 2015;91:47-83.

3. Hao L, Xie J, Chen S, Wang S, Gong Z, Ling KS, Guo L, Fan Z, Zhou T. A multiple RT-PCR assay for simultaneous detection and differentiation of latent viruses and apscarvioids in apple trees. J Virol Methods. 2016;234:16-21.

4. Wu QF, Ding SW, Zhang YJ, Zhu SF. Identification of viruses and viriods by next-generation sequencing and homology-dependent and homologyindependent algorithms. Annu Rev Phytopathol. 2015;53:425-44.

5. Li R, Mock R, Huang Q, Abad J, Hartung J, Kinard G. A reliable and inexpensive method of nucleic acid extraction for the PCR-based detection of diverse plant pathogens. J Virol Methods. 2008:154:48-55.

6. Kumar S, Stecher G, Tamura K. MEGA7: molecular evolutionary genetics analysis version 7.0 for bigger datasets. Mol. Biol. Evolution. 2016;33:1870-4

7. Martin DP, Murrell B, Golden M, Khoosal A, Muhire B. RDP4: detection and analysis of recombination patterns in virus genomes. Virus Evol. 2015;1: vev003. https://doi.org/10.1093/ve/vev003.

8. Domier LL, McCoppin NK, Larsen RC, D'Arcy CJ. Nucleotide sequence shows that bean leafroll virus has a Luteovirus-like genome organization. J Gen Virol. 2002;83:1791-8.

9. Miller A, Jackson J, Feng Y. Cis- and trans-regulation of luteovirus gene expression by the $3^{\prime}$ end of the viral genome. Virus Res. 2015;206:37-45.

10. Ali M, Hameed S, Tahir M. Luteovirus: insights into pathogenicity. Arch Virol. 2014;159:2853-60.

11. Salem NM, Miller WA, Rowhani A, Golino DA, Moyne AL, Falk BW. Rose spring dwarf-associated virus has RNA structural and gene-expression features like those of barley yellow dwarf virus. Virol. 2008:375:354-60.

12. Villamor DEV, Mekuria TA, Pillai SS, Eastwell KC. High-throughput sequencing identifies novel virus in nectarine: insights to the etiology of stem-pitting disease. Phytopathology. 2016;106:519-27.

13. Lenz O, Přibylova J, Fránová J, Koloniuk I, Spak J. Identification and characterization of a new member of the genus Luteovirus from cherry. Arch Virol. 2017;162:587-90.

14. Wu LP, Liu HW, Bateman M, Liu Z, Li R. Molecular characterization of a nove luteovirus from peach identified by high-throughput sequencing. Arch Virol. 2017;162:2903-5.

15. Smirnova E, Firth AE, Miller WA, Scheidecker D, Brault V, Reinbold C, Rakotondrafara AM, Chung BYW, Ziegler-Graff V. Discovery of a small nonAUG-initiated ORF in poleroviruses and luteoviruses that isrequired for longdistance movement. PLoS Pathog. 2015:ppat.1004868.

16. Vives MC, Velázquez K, Pina JA, Moreno P, Guerri J, Navarro L. Identification of a new enamovirus associated with citrus vein enation disease by deep sequencing of small RNAs. Phytopathology. 2013;103:1077-86.

17. Domier LL. Luteoviridae. In: AMQ K, Adams MJ, Carstens EB, Lefkowitz EJ, editors. Virus taxonomy, ninth report of the international committee on taxonomy of viruses: Elsevier Academic Press; 2012. p. pp1045-53.

18. Wu B, Blanchard-Letort A, Liu Y, Zhou G, Wang X, Elena SF. Dynamics of molecular evolution and phylogeography of Barley yellow dwarf virus-PAV. PLoS One. 2011;6:e16896. https://doi.org/10.1371/journal.pone.0016896.

19. Rosenberger DA, Harrison MB, Gonsalvers D. Incidence of apple union necrosis and decline, tomato ringspot virus, Xiphinema vector species in Hudson valley orchards. Plant Dis. 1983;67:356-60. 
20. Moreno P, Ambros S, Albiach-Mart MR, Guerri J, Pena L. Citrus tristeza virus: a pathogen that changed the course of the citrus industry. Mol Plant Pathol. 2008:9:251-8.

21. Matsumura EE, Coletta-Filho HD, de Oliverira-Dorta S, Nourin S, Machado MA. Genetic structure and molecular variability analysis of Citrus sudden deathassociated virus isolates form infected plants grown in Brazil. Viruses. 2016;9:1.

22. Salem N, Golino DA, Falk BW, Rowhani A. Identification and partial characterization of a new luteovirus associated with rose spring dwarf disease. Plant Dis. 2008;92:508-12

Ready to submit your research? Choose BMC and benefit from:

- fast, convenient online submission

- thorough peer review by experienced researchers in your field

- rapid publication on acceptance

- support for research data, including large and complex data types

- gold Open Access which fosters wider collaboration and increased citations

- maximum visibility for your research: over $100 \mathrm{M}$ website views per year 